\section{Rapid Determination of Nitrogen Status in Pansy}

\author{
James E. Altland ${ }^{1}$, Charles H. Gilliam², Gary J. Keever², \\ James H. Edwards ${ }^{3}$, Jeff L. Sibley ${ }^{4}$, and Donna C. Fare ${ }^{5}$ \\ Department of Horticulture, Auburn University, Auburn, AL 36849
}

Additional index words. nitrate, potted plant production, landscape crops, Cardy nitrate meter

\begin{abstract}
Two experiments were conducted with pansy (Viola $\times$ wittrockiana Gams 'Bingo Yello') to determine the relationship between foliar nitrogen (\% of dry weight) (FN) and either sap nitrate concentration (SN) in petioles or SPAD readings of foliage. FN was highly correlated to $\mathrm{SN}$ throughout both experiments $(r=0.80$ to 0.91$)$. FN was poorly correlated to SPAD readings early in both experiments $(r=0.54$ to 0.65$)$, but more highly correlated later when visual symptoms of $\mathrm{N}$ deficiency were apparent $(r=0.84$ to 0.90$)$. SN determined with the Cardy sap nitrate meter was a reliable predictor of $\mathrm{FN}$ in pansy, while SPAD readings were only reliable after symptoms of $\mathbf{N}$ deficiency were visually evident. FN can be predicted with $\mathrm{SN}$ using the following equation: $\log (\mathrm{SN})=0.47 * \mathrm{FN}+1.6\left[r^{2}=0.80\right.$, $n=132$ ]. Growers and landscape professionals can use $S N$ readings to predict FN levels in pansy, and thus rapidly and accurately diagnose the $\mathbf{N}$ status of their crop.
\end{abstract}

Nutritional monitoring, especially of nitrogen $(\mathrm{N})$ status, is an important component of growing quality container plants. With bedding plants, either in flats or individual containers, $\mathrm{N}$ deficiency may occur rapidly and limit plant growth at a time when maximum growth is critical for sales. In container nursery and greenhouse crops, measuring plant $\mathrm{N}$ status can be accomplished by several methods. Laboratory analysis of tissue samples, albeit reliable, entails shipping and lab processing, and therefore does not allow for rapid diagnosis and immediate response. Another more rapid technique for monitoring nutritional status of container-grown crops is a pour-through method, which correlates soluble salt levels in container leachate with available nutrients in the container substrate (Yeager et al., 1983). This method offers rapid approximation of the nutrient status potentially available to the plant, and thus allows the grower to make frequent fertility adjustments to maximize growth and marketability. Guidelines for many container crops have been reported using this method (Yeager et al., 1997; Fonteno et al., 1996), however, use of different substrate, fertilizer sources, irrigation water quality, and moisture level at the time of measurement will affect final readings and can cause confusion (Kirven, 1986). While pour-through methods offer valuable information regarding nutrients potentially available to the plant, the most accurate way to assess the nutritional status of a crop is to analyze both plant tissue and substrate in which the plant is growing (Smith, 1962).

Received for publication 28 Jan. 2002. Accepted for publication 25 June 2002.

${ }^{1}$ Assistant Professor of Horticulture, Oregon State Univ.

${ }^{2}$ Professor of Horticulture.

${ }^{3}$ Soil Scientist, USDA-ARS, deceased.

${ }^{4}$ Associate Professor of Horticulture.

${ }^{5}$ Horticulture Scientist, USDA-ARS, National Arboretum, McMinnville, Tenn.
A method for rapidly diagnosing $\mathrm{N}$ status in landscape-grown crops would also be beneficial to landscape professionals. Landscape professionals cannot rely on pour-through methods for determining the nutritional status of landscape plants. Only laboratory analysis of substrate or plant tissue is reliable for accurate diagnosis. These procedures take time and do not allow for rapid diagnosis and immediate reaction to nutritional deficiencies.

In addition to preventing $\mathrm{N}$ deficiency in landscape-grown bedding plants, rapid diagnosis of $\mathrm{N}$ status would allow landscape professionals to apply $\mathrm{N}$ according to plant need and therefore reduce excess nutrient leaching to groundwater and streams. Nitrate-nitrogen $\left(\mathrm{NO}_{3}^{-}-\mathrm{N}\right)$ is mobile in soil and often leached into groundwater systems (Marschner, 1997). Urban consumers are becoming increasingly aware of environmental impacts from agricultural, nursery, and landscape practices. Nonpoint source pollution (NPS) from urban landscapes has been implicated in contributing to the nutrient load in water bodies throughout the United States (Hairston and Stribling, 1995). Increased awareness has led many researchers in agronomic and horticultural sciences to evaluate nutritional programs that minimize nutrient leaching from fertilizer applications. Strategies evaluated to improve nitrogen use efficiency (NUE) include use of various fertilizer types (Diez et al, 1994), methods of application (Timmons and Dylla, 1981), and rates of application (Syvertson and Smith, 1995). Others have reported improved NUE by using multiple applications of fertilizer, where the total amount of applied $\mathrm{N}$ is split into several applications throughout the year (Guertal, 2000). However, the exact time at which plants require fertilizer inputs is difficult to determine unless some method of monitoring is used to determine plant $\mathrm{N}$ status. Applying $\mathrm{N}$ based on plant need could increase NUE, improve plant growth and reduce excess leaching of N. Coltman (1988) reported N applications to tomato plants based on maintenance of plant sap nitrate levels resulted in less $\mathrm{N}$ use over the growing season, thus improving plant NUE. Similarly, Hesselein et al. (2000) demonstrated improved growth of Boston fern (Nephrolepsis exaltata) by applying $\mathrm{N}$ based on soluble salt levels in container leachate.

The wholesale value of potted pansy production in 2000 was estimated to be $\$ 21.3$ million (National Agriculture Statistics Board, 2001), and pansy ranks fourth in popularity among landscape bedding plants (Miller, 2000). Methods for rapid determination of pansy $\mathrm{N}$ status adaptable to the greenhouse, nursery, and landscape industries include SPAD meters (Minolta, Ramsey, N.J.), which measure relative chlorophyll content in foliage, and portable nitrate meters that measure nitrate concentration in plant sap. SPAD meter readings are nondestructive and work by spectrophotometrically determining chlorophyll content in plant foliage. SPAD readings have been correlated with $\mathrm{N}$ status for a wide variety of crops including cotton (Gossypium sp.) (Wood et al., 1992), corn (Zea mays) (Bullock and Anderson, 1998), apple (Malus $\times$ domestica Borkh) (Neilsen et al., 1995), and potato (Solanum tuberosum) (Minotti et al., 1994). However, determining a single calibration or sufficiency range for a crop is often difficult when there is variation in leaf types (thickness, shape, variegation, etc.) within a species (Neilsen et al., 1995; Minotti et al., 1994).

Nitrate concentration in plant sap as a measure of plant $\mathrm{N}$ status has been shown to be reliable for many crops. Petioles are typically used because they are not sites of active metabolism but conductive tissue used for nitrate transport and storage. Petiole analysis is indicative of the balance between nitrate supply in the substrate and its utilization in the leaves (Mills and Jones, 1996). Two devices, the Hach electrode (The Hach Co., Loveland, Colo.) and the Cardy nitrate meter (Horiba, Kyoto, Japan), utilize nitrate specific electrodes for making quantitative determinations of nitrate concentration. Results from using the two devices to determine nitrate concentration in potato were highly correlated to each other, and highly correlated to results from a laboratory grade Wescan N analyzer (Rosen et al., 1996). The Hach electrode requires sample dilution while the Cardy meter does not, making the Cardy meter more practical for field applications. The Cardy nitrate meter is portable and can determine nitrate concentration in plant sap over a range of 1 to $10,000 \mathrm{mg} \cdot \mathrm{L}^{-1}$ nitrate. This methodology has been shown reliable for use in potatoes (Rosen et al., 1996), cauliflower (Brassica oleracea Botrytis Group) (Kubota et al., 1996), tomatoes (Lycopersicon esculentum Mill.) (Beverly, 1994), and cereal forages (Delgado and Follett, 1998). This methodology is not suitable for all crops. Begonia (Begonia elatior) reduces most absorbed nitrate in roots (Schenk, 1988), and thus nitrate levels in petioles are not indicative of changes in the level of absorbed nitrate.

A procedure that allows for rapid determination of $\mathrm{N}$ status in potted or landscape grown pansies would allow growers and 
landscape professionals to make frequent fertilizer adjustments to their crops. Therefore, the objective of this study was to evaluate the Cardy nitrate meter and the SPAD-502 leaf chlorophyll meter for rapidly determining $\mathrm{N}$ status in pansy.

\section{Material and Methods}

Expt. 1. Pansy (Viola $\times$ wittrockiana Gams 'Bingo Yellow') were transplanted 16 Nov. 2000 from 48-cell packs into 20 -cm (8-inch) diameter azalea pots with a 3 pinebark: 1 peat (by volume) medium amended per $\mathrm{m}^{3}$ ( yard $^{3}$ ) with $3.0 \mathrm{~kg}(5 \mathrm{lb})$ of dolomitic limestone and $0.9 \mathrm{~kg}$ (1.5 lb) of Micromax (Scotts Co., Marysville, Ohio) micronutrients. Plants were grown in a double polyethylene greenhouse under natural photoperiod with heat/vent set points of 13/18 ${ }^{\circ} \mathrm{C}\left(55 / 65^{\circ} \mathrm{F}\right)$. At two of every three irrigation events plants were watered with a solution of the concentration: $160 \mathrm{mg} \cdot \mathrm{L}^{-1} \mathrm{~N}$ from ammonium nitrate $\left(\mathrm{NH}_{4} \mathrm{NO}_{3}\right), 62 \mathrm{mg} \cdot \mathrm{L}^{-1}$ phosphorus $(\mathrm{P})$ and $150 \mathrm{mg} \cdot \mathrm{L}^{-1}$ potassium $(\mathrm{K})$ from potassium phosphate $\left(\mathrm{K}_{2} \mathrm{HPO}_{4}\right)$. Plants were watered with tap water every third irrigation. On 7 Dec., uniform plants $\approx 7 \mathrm{~cm}$ (2.8 in) tall and $18 \mathrm{~cm}(7.1 \mathrm{in})$ wide were selected from a larger group for use in the experiment. Plants were fertilized with $62 \mathrm{mg} \cdot \mathrm{L}^{-1} \mathrm{P}, 150 \mathrm{mg} \cdot \mathrm{L}^{-1} \mathrm{~K}$, and either $40,80,120$, or $160 \mathrm{mg} \cdot \mathrm{L}^{-1} \mathrm{~N}$ using salts and frequencies previously mentioned. Nitrogen treatments were designed to produce plants with $\mathrm{N}$ status ranging from deficient to excessive (Fonteno et al., 1996). Fertilizer salts were mixed in plastic containers and applied at a rate of $450 \mathrm{~mL}(15 \mathrm{oz})$ per container per irrigation event. Plants were arranged in a completely randomized design on above ground benches. Six single plant replicates were destructively harvested 15,35 , and $50 \mathrm{~d}$ after initial treatment (DAT). Data collected included growth index [(height + width + width) / 3] and flower number. Recently- matured foliage was used for SPAD readings (SPAD-502), petiole sap nitrate determination, and foliar N (\% dry weight basis). For petiole sap nitrate determination, petioles of recently matured leaves $(\approx 12$ petioles per plant) were excised and placed into a modified garlic press (Spectrum Technologies, Plainfield, Ill.) and crushed to exude petiole sap. Sap was absorbed onto sample paper (Spectrum Technologies) which was placed onto the sensor of a Cardy nitrate ion meter. Recently matured foliage $(\approx 40$ leaves per plant) was also collected, rinsed with deionized water, dried, and ground for laboratory determination of total N (\%) using a Leco CN 2000 (Leco Corp., St. Joseph, Mich.). Substrate leachates were collected 35 DAT using a pour-through method (Yeager et al., 1983). Containers were irrigated with a nutrient solution the day prior to leachate collection. At collection, $200 \mathrm{ml}$ of deionized water was applied to the container surface, and leachates were collected and analyzed for nitrate and ammonium (Sims et al., 1995).

Expt. 2. Expt. 2 was conducted similarly to Expt. 1 with a few exceptions. Pansy were potted 10 Mar. 2001 and the first fertilizer treatment was applied 2 Apr. 2001. Plants were grown under natural photoperiod and heat/vent set points of $16 / 21{ }^{\circ} \mathrm{C}\left(60 / 70{ }^{\circ} \mathrm{F}\right)$ (though temperatures often reached as high as $24^{\circ} \mathrm{C}\left(75^{\circ} \mathrm{F}\right)$. Eight rates of $\mathrm{N}$ were used: 20 , $40,60,80,100,120,140$, and $160 \mathrm{mg} \cdot \mathrm{L}^{-1} \mathrm{~N}$. Plants were harvested 18, 35, and 46 DAT.

Data in both experiments were analyzed with regression analysis, and regression diagnostics were used to determine the most appropriate (if any) transformation of variables.

\section{Results and Discussion}

Expt. 1. At 14 DAT there were no differences in growth, SPAD readings, or flower number in response to $\mathrm{N}$ rate (Table 1). Despite similar growth and plant appearance, petiole sap nitrate $\left(\mathrm{NO}_{3}^{-}-\mathrm{N}\right)$ levels $(\mathrm{SN})$ and foliar nitrogen (FN) (\% total-N on a dry weight basis) increased linearly with increasing $\mathrm{N}$ rate. Pansy fertilized with the low $\mathrm{N}$ rate ( 40 $\left.\mathrm{mg} \cdot \mathrm{L}^{-1} \mathrm{~N}\right)$ appeared similar to other plants receiving higher $\mathrm{N}$ rates, yet foliar analysis revealed FN levels were lower than those reported as acceptable by Mills and Jones (1996) (3.4\% to $4.2 \%)$. There is discrepancy in the literature regarding acceptable ranges for FN, for example, Fonteno et al. (1996) reported $2.5 \%$ to $4.5 \%$ as being acceptable. This indicates FN analysis can predict deficient levels of $\mathrm{N}$ before visual symptoms of nutrient deficiency occur. Sap nitrate meters and SPAD meters have been used to diagnose $\mathrm{N}$ deficiency with other crops, as previously discussed. At 14DAT, correlation between FN and SN was high $(r=0.88)$ (Table 2), while correlation between FN and SPAD readings was marginal $(r=0.65)$. This indicates that $\mathrm{SN}$ could be used to predict FN and thus $\mathrm{N}$ deficiency before visual symptoms occur, while SPAD readings would not be as reliable in predicting FN nor $\mathrm{N}$ deficiency. For purposes of this paper, $\mathrm{N}$ deficiency will be defined as plants having FN levels lower than 2.5\% (Fonteno et al., 1996).

At 35 DAT, values of all measured parameters increased linearly with increasing $\mathrm{N}$ rate. FN levels for plants receiving 40 and $80 \mathrm{mg} \cdot \mathrm{L}^{-1}$ $\mathrm{N}$ were lower than those recommended in the literature. FN and SN were again highly correlated $(r=0.90)$, and correlation between FN and SPAD readings was higher $(r=0.88)$ than at 14 DAT. As plant foliar color began to respond to $\mathrm{N}$ rate, $\mathrm{SPAD}$ readings became more reliable as a predictor of FN and thus plant $\mathrm{N}$ status. Trends at 50 DAT were similar to those at 35 DAT.

SN data were regressed against FN to determine the nature of their relationship. Regression diagnostics indicated a logarithmic (base
Table 1. Pansy response to N rate, Expt. 1.

\begin{tabular}{|c|c|c|c|c|c|}
\hline $\begin{array}{l}\mathrm{N} \text { rate } \\
\left(\mathrm{mg} \cdot \mathrm{L}^{-1}\right)\end{array}$ & $\begin{array}{c}\text { Flower } \\
\text { no. }\end{array}$ & $\begin{array}{l}\text { G.I. }{ }^{z} \\
(\mathrm{~cm})\end{array}$ & SPAD & $\begin{array}{c}\mathrm{SN}^{\mathrm{y}} \\
\left(\mathrm{mg} \cdot \mathrm{L}^{-1}\right)\end{array}$ & $\begin{array}{l}\mathrm{FN}^{\mathrm{x}} \\
(\%)\end{array}$ \\
\hline & & & 14 DAT" & & \\
\hline 40 & 2.3 & 14.9 & 51.5 & 534 & 2.9 \\
\hline 80 & 2.8 & 15.3 & 51.5 & 1960 & 3.6 \\
\hline 120 & 2.3 & 16.1 & 53.1 & 2900 & 4.0 \\
\hline \multirow[t]{2}{*}{160} & 2.7 & 16.1 & 54.5 & 4517 & 4.3 \\
\hline & $\mathrm{NS}^{\mathrm{v}}$ & NS & NS & $\mathrm{L}^{* * *}$ & $\mathrm{~L}^{* * *}$ \\
\hline 40 & 4.0 & 15.1 & 44.7 & 354 & 2.0 \\
\hline 80 & 4.7 & 18.1 & 51.4 & 370 & 2.5 \\
\hline 120 & 5.3 & 19.7 & 57.9 & 1230 & 3.2 \\
\hline \multirow[t]{2}{*}{160} & 6.7 & 20.7 & 58.6 & 2450 & 3.5 \\
\hline & $\mathrm{L}^{*}$ & $\mathrm{~L}^{* * * *}$ & $\mathrm{~L}^{* * *}$ & $\mathrm{~L}^{* * *}$ & $\mathrm{~L}^{* * *}$ \\
\hline 40 & 3.7 & 17.7 & 44.7 & 388 & 1.7 \\
\hline 80 & 6.0 & 19.4 & 52.0 & 778 & 2.7 \\
\hline 120 & 8.3 & 21.4 & 59.3 & 2108 & 3.4 \\
\hline \multirow[t]{2}{*}{160} & 9.2 & 22.7 & 62.5 & 5300 & 3.9 \\
\hline & $\mathrm{L}^{* *}$ & $\mathrm{~L}^{* * *}$ & $\mathrm{~L}^{* * *}$ & $\mathrm{~L}^{* * *} \mathrm{Q}^{* * *}$ & $\mathrm{~L}^{* * *}$ \\
\hline
\end{tabular}

${ }^{2}$ Growth index: (height + width + width) / 3 .

${ }^{y}$ Sap nitrate concentration.

${ }^{x}$ Foliar nitrogen (\% of dry weight).

${ }^{\text {ww } D a y s ~ a f t e r ~ t r e a t m e n t . ~}$

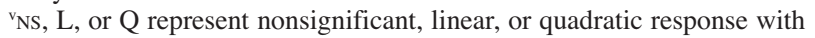
increasing $\mathrm{N}$ rate.

${ }^{*, * *, * * *}$ Significance at $0.05,0.01$, or 0.001 level, respectively.
Table 2. Correlation matrix ${ }^{\mathrm{z}}$ for measured parameters of pansy, Expt 1.

\begin{tabular}{|c|c|c|c|c|}
\hline & \multicolumn{4}{|c|}{ Correlation coefficients $(r)$} \\
\hline & $\bar{N}$ Rate $\left(\mathrm{mg} \cdot \mathrm{L}^{-1}\right)$ & SPAD & $\mathrm{SN}^{y}\left(\mathrm{mg} \cdot \mathrm{L}^{-1}\right)$ & $\mathrm{FN}^{\mathrm{x}}(\%)$ \\
\hline N Dote $(\mathrm{mol}-1)$ & ------------- & -14 & $\mathrm{AT}^{\mathrm{w}}$ & \\
\hline $\begin{array}{l}\text { N Rate }\left(\mathrm{mg} \cdot \mathrm{L}^{-1}\right) \\
\text { SPAD }\end{array}$ & $\begin{array}{l}1.00 \\
0.33\end{array}$ & 100 & & \\
\hline $\mathrm{SN}\left(\mathrm{mg} \cdot \mathrm{L}^{-1}\right)$ & 0.89 & 0.56 & 1.00 & \\
\hline $\mathrm{FN}(\%)$ & 0.84 & 0.65 & 0.88 & 1.00 \\
\hline N Rate $\left(\mathrm{mg} \cdot \mathrm{L}^{-1}\right)$ & 1.00 & & & \\
\hline SPAD & 0.80 & 1.00 & & \\
\hline $\mathrm{SN}\left(\mathrm{mg} \cdot \mathrm{L}^{-1}\right)$ & 0.81 & 0.76 & 1.00 & \\
\hline $\mathrm{FN}(\%)$ & 0.87 & 0.88 & 0.90 & 1.00 \\
\hline N Rate $\left(\mathrm{mg} \cdot \mathrm{L}^{-1}\right)$ & 1.00 & & & \\
\hline SPAD & 0.88 & 1.00 & & \\
\hline $\mathrm{SN}\left(\mathrm{mg} \cdot \mathrm{L}^{-1}\right)$ & 0.96 & 0.87 & 1.00 & \\
\hline $\mathrm{FN}(\%)$ & 0.91 & 0.90 & 0.89 & 1.00 \\
\hline
\end{tabular}

${ }^{2}$ Matrix of numbers representing Pearson's correlation coefficient $(r)$ between row and column parameters.

${ }^{\mathrm{y}} \mathrm{Sap}$ nitrate concentration.

${ }^{x}$ Foliar nitrogen (\% of dry weight).

"Days after treatment. 
10) transformation of SN data was necessary to homogenize the variance (Neter et al., 1996); actual data are reported in the table (Table 1). The date at which data were collected was entered into the model to determine differences in response among the three collection dates. Regression analysis indicated the slope and intercept for the line were similar at all three dates, so data were pooled for analysis. FN regressed against $\mathrm{SN}$ revealed the following equation for the line of best fit: $\log (\mathrm{SN})=$ $0.48 * \mathrm{FN}+1.6\left[\left(r^{2}=0.78, \mathrm{n}=61\right)\right]$ (Fig. 1$)$. The $95 \%$ confidence interval for the slope of the line of best fit was $[0.42,0.55]$.

SPAD data were also regressed against FN to determine the nature of that relationship. Unlike SN data, the relationship between SPAD and FN changed at each collection date. At 14 DAT the relationship was significant though weak: SPAD $=3.8 * \mathrm{FN}+39.2\left[\left(r^{2}=0.42, \mathrm{n}=\right.\right.$ 18)] (Fig. 2). The relationships between SPAD and $\mathrm{FN}$ at 35 and 50 DAT were similar and more consistent: $\mathrm{SPAD}=7.7 * \mathrm{FN}+32.0\left[\left(r^{2}=0.76\right.\right.$, $\mathrm{n}=44)]$. Because SPAD meters measure the "greenness" of plant foliage (Mills and Jones, 1996), they can be effective in predicting FN, and thus $\mathrm{N}$ status, when visual symptoms of $\mathrm{N}$ deficiency (chlorosis) have already occurred. However, they are not reliable in predicting FN levels prior to the occurrence of deficiency symptoms.
Nitrogen was applied as ammonium nitrate. If a significant portion of $\mathrm{N}$ absorbed by the plant is ammonium, nitrate levels in sap will not fluctuate with increases or decreases in absorbed $\mathrm{N}$, and thus will not be indicative of the $\mathrm{N}$ status of the plant. In leachates collected from pots 35 DAT, nitrate constituted $76 \%$ to $97 \%$ of the total inorganic $\mathrm{N}\left(\mathrm{NO}_{3}{ }^{-} \mathrm{N}+\mathrm{NH}_{4}^{+}-\right.$ $\mathrm{N}$ ) in the leachate (Table 3). Similarly, Schenk (1988) reported small amounts of ammonium in container substrate despite supplying $\mathrm{N}$ in the form of ammonium nitrate, and Cabrera (1997) reported $85 \%$ of $\mathrm{N}$ in container leachate was nitrate, regardless of $\mathrm{N}$ form used in various controlled-release fertilizers. Because ammonium is oxidized to nitrate rapidly in containers and under field conditions (Marschner, 1997), sap nitrate meters should be reliable regardless of the $\mathrm{N}$ form used or the $\mathrm{N}$ form preferentially absorbed by the plant.

Expt. 2. When plants were harvested 18 DAT, there were few obvious differences in appearance, in response to $\mathrm{N}$ rate. Plants were similar in size and flower number (Table 4), though a slight increase in foliar color with increasing $\mathrm{N}$ rate was apparent. FN and SN levels increased linearly with increasing $\mathrm{N}$ rate and were well correlated to each other $(r=0.80)$ (Table 5). Though SPAD readings increased linearly with increasing $\mathrm{N}$ rate, SPAD correlation with FN was low $(r=0.54)$. As in Expt.
Table 3. Inorganic nitrogen $(\mathrm{N})$ fraction in container leachate 35 DAT, Expt. 1.

\begin{tabular}{lccc}
\hline $\begin{array}{l}\mathrm{N} \text { Rate } \\
\left(\mathrm{mg} \cdot \mathrm{L}^{-1}\right)\end{array}$ & $\begin{array}{c}\mathrm{NH}_{4}{ }^{+}-\mathrm{N} \\
\left(\mathrm{mg} \cdot \mathrm{L}^{-1}\right)\end{array}$ & $\begin{array}{c}\mathrm{NO}_{3}^{-}-\mathrm{N} \\
\left(\mathrm{mg} \cdot \mathrm{L}^{-1}\right)\end{array}$ & $\begin{array}{c}\mathrm{NO}_{3}^{-}-\mathrm{N}^{2} \\
(\%)\end{array}$ \\
\hline 40 & 1.1 & 36.5 & 97 \\
80 & 2.9 & 19.3 & 80 \\
120 & 9.9 & 31.6 & 76 \\
160 & 10.0 & 34.8 & 78 \\
\hline
\end{tabular}

${ }^{2}$ Percentage of the total inorganic $\mathrm{N}$ content composed of $\mathrm{NO}_{3}^{-}-\mathrm{N}$.

1 , SPAD readings were again poor predictors of FN and thus $\mathrm{N}$ deficiency, while $\mathrm{SN}$ values were good predictors of FN.

At 35 DAT all measured parameters increased linearly with increasing $\mathrm{N}$ rates. Differences in SPAD values (foliar greenness) were pronounced, with all plants receiving $\leq 100 \mathrm{mg} \cdot \mathrm{L}^{-1} \mathrm{~N}$ appearing deficient while those receiving $\geq 120 \mathrm{mg} \cdot \mathrm{L}^{-1} \mathrm{~N}$ had dark foliage and appeared healthy. Similar to Expt. 1, when foliar color responded to $\mathrm{N}$ rate, SPAD readings were highly correlated with $\mathrm{FN}(r=$ 0.86). These data verify results of Expt. 1 in that $\mathrm{SN}$ values are a reliable predictor of $\mathrm{FN}$ and $\mathrm{N}$ deficiency in pansy before visual symptoms of deficiency occur, while SPAD meter values are poor predictors of $\mathrm{FN}$ and $\mathrm{N}$ deficiency. Data collected 46 DAT were similar to those at 35 DAT, except that flower numbers were similar among all $\mathrm{N}$ rates.

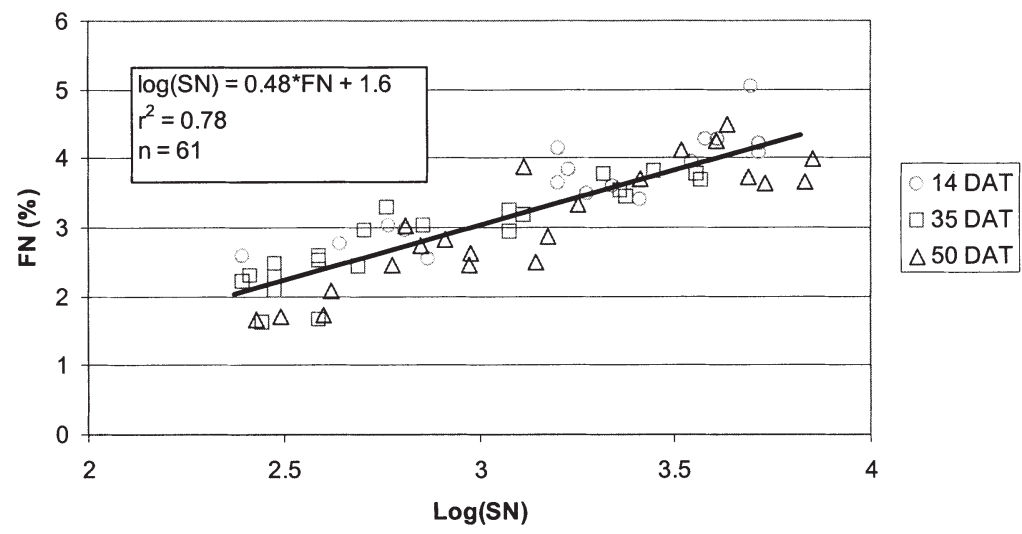

Table 4. Pansy response to $\mathrm{N}$ rate, Expt. 2.

\begin{tabular}{|c|c|c|c|c|c|}
\hline $\begin{array}{l}\text { rate } \\
\left(\mathrm{mg} \cdot \mathrm{L}^{-1}\right)\end{array}$ & $\begin{array}{c}\text { Flower } \\
\text { no. }\end{array}$ & $\begin{array}{l}\text { G.I. }^{z} \\
(\mathrm{~cm})\end{array}$ & SPAD & $\begin{array}{c}\mathrm{SN}^{\mathrm{y}} \\
\left(\mathrm{mg} \cdot \mathrm{L}^{-1}\right)\end{array}$ & $\begin{array}{l}\mathrm{FN}^{\mathrm{x}} \\
(\%)\end{array}$ \\
\hline & & & 18 DAT & & \\
\hline 20 & 6.7 & 16.2 & 47.3 & 342 & 1.8 \\
\hline 40 & 5.7 & 14.8 & 49.7 & 520 & 2.0 \\
\hline 60 & 9.0 & 18.2 & 49.0 & 493 & 1.9 \\
\hline 80 & 7.7 & 16.3 & 50.4 & 467 & 2.3 \\
\hline 100 & 6.8 & 17.3 & 49.2 & 720 & 2.4 \\
\hline 120 & 7.8 & 19.1 & 51.5 & 790 & 2.4 \\
\hline 140 & 7.3 & 17.1 & 52.6 & 2055 & 2.7 \\
\hline \multirow[t]{2}{*}{160} & 4.8 & 16.8 & 56.7 & 2375 & 2.9 \\
\hline & $\mathrm{NS}^{\mathrm{v}}$ & NS & $\mathrm{L}^{*}$ & $\mathrm{~L}^{* * *} \mathrm{Q}^{*}$ & $\mathrm{~L}^{* * * *}$ \\
\hline 20 & 5.0 & 17.3 & 35.7 & 170 & 1.4 \\
\hline 40 & 7.4 & 17.1 & 44.3 & 224 & 1.7 \\
\hline 60 & 12.2 & 19.4 & 44.3 & 284 & 2.0 \\
\hline 80 & 9.4 & 19.5 & 46.1 & 456 & 2.4 \\
\hline 100 & 11.0 & 19.6 & 50.1 & 598 & 2.5 \\
\hline 120 & 10.8 & 20.6 & 53.8 & 780 & 2.7 \\
\hline 140 & 12.8 & 21.5 & 55.5 & 1052 & 3.0 \\
\hline \multirow[t]{2}{*}{160} & 12.3 & 23.0 & 55.3 & 1263 & 2.9 \\
\hline & $\mathrm{L}^{* *}$ & $\mathrm{~L}^{* * * *}$ & $\mathrm{~L}^{* * *} \mathrm{Q}^{*}$ & $\mathrm{~L}^{* * *}$ & $\mathrm{~L}^{* * *}$ \\
\hline 20 & 9.2 & 16.6 & 32.2 & 230 & 1.2 \\
\hline 40 & 9.4 & 16.5 & 37.3 & 270 & 1.5 \\
\hline 60 & 10.6 & 17.4 & 44.8 & 283 & 1.8 \\
\hline 80 & 11.8 & 18.2 & 47.5 & 430 & 2.3 \\
\hline 100 & 13.5 & 19.1 & 49.9 & 908 & 2.6 \\
\hline 120 & 12.0 & 19.8 & 50.0 & 1772 & 2.9 \\
\hline 140 & 12.2 & 21.4 & 51.5 & 1946 & 3.0 \\
\hline \multirow[t]{2}{*}{160} & 12.7 & 22.3 & 53.2 & 2925 & 3.5 \\
\hline & NS & $\mathrm{L}^{* * *}$ & $\mathrm{~L}^{* * *} \mathrm{Q}^{* *}$ & $\mathrm{~L}^{* * *}$ & $\mathrm{~L}^{* * *}$ \\
\hline
\end{tabular}

${ }^{2}$ Growth index: (height + width + width) / 3 .

Sap nitrate concentration.

${ }^{x}$ Foliar nitrogen (\% of dry weight).

"Days after treatment.

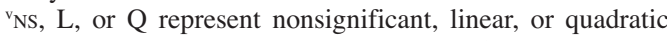
response with increasing $\mathrm{N}$ rate, respectively.

${ }^{* * * * * * * * *}$ Significance at $0.05,0.01$, or 0.001 levels, respectively.

Fig. 2. Relationship between foliar nitrogen (FN) and SPAD readings, Expt. 1. 
Table 5. Correlation matrix ${ }^{z}$ for measured parameters of pansy, Expt. 2.

\begin{tabular}{|c|c|c|c|c|}
\hline & $\mathrm{N}$ rate $\left(\mathrm{mg} \cdot \mathrm{L}^{-1}\right)$ & SPAD & $\mathrm{SN}^{y}\left(\mathrm{mg} \cdot \mathrm{L}^{-1}\right)$ & $\mathrm{FN}^{\mathrm{x}}(\%)$ \\
\hline $\mathrm{N}$ rate $\left(\mathrm{mg} \cdot \mathrm{L}^{-1}\right)$ & \multicolumn{4}{|l|}{-------- } \\
\hline SPAD & 0.39 & \multicolumn{3}{|l|}{1.00} \\
\hline $\mathrm{SN}\left(\mathrm{mg} \cdot \mathrm{L}^{-1}\right)$ & 0.85 & 0.51 & \multicolumn{2}{|l|}{1.00} \\
\hline $\mathrm{FN}(\%)$ & 0.83 & 0.54 & 0.80 & 1.00 \\
\hline $\mathrm{N}$ rate $\left(\mathrm{mg} \cdot \mathrm{L}^{-1}\right)$ & \multicolumn{4}{|l|}{1.00} \\
\hline SPAD & 0.81 & \multicolumn{3}{|l|}{1.00} \\
\hline $\mathrm{SN}\left(\mathrm{mg} \cdot \mathrm{L}^{-1}\right)$ & 0.65 & 0.77 & 1.00 & \multirow[b]{2}{*}{1.00} \\
\hline $\mathrm{FN}(\%)$ & 0.85 & 0.86 & 0.88 & \\
\hline $\mathrm{N}$ rate $\left(\mathrm{mg} \cdot \mathrm{L}^{-1}\right)$ & 1.00 & & & \\
\hline SPAD & 0.84 & 1.00 & & \\
\hline $\mathrm{SN}\left(\mathrm{mg} \cdot \mathrm{L}^{-1}\right)$ & 0.87 & 0.73 & 1.00 & \\
\hline $\mathrm{FN}(\%)$ & 0.91 & 0.84 & 0.91 & 1.00 \\
\hline $\begin{array}{l}{ }^{2} \text { Matrix of num } \\
\text { between row an } \\
\text { 'Sap nitrate con } \\
{ }^{\text {x}} \text { Foliar nitrogen } \\
\text { "Days after trea }\end{array}$ & $\begin{array}{l}\text { rs representing } \\
\text { column paramet } \\
\text { ntration. } \\
\text { \% of dry weight } \\
\text { ent. }\end{array}$ & $\begin{array}{l}\text { Pearso } \\
\text { rs. }\end{array}$ & orrelation & cient $(r$ \\
\hline
\end{tabular}

FN was regressed against $\mathrm{SN}$ to determine the equation for the line of best fit. Similar to Expt. 1, logarithmic transformation of SN was necessary to meet regression assumptions. Fitted equations at 35 and 46 DAT were similar while the equation at 18 DAT differed slightly and had a lower $r^{2}$. The fitted equation for 18 DAT was: $\log (\mathrm{SN})=0.52 * \mathrm{FN}+1.7\left[r^{2}=0.63\right.$, $\mathrm{n}=29]$ with a $95 \%$ confidence interval of the slope [0.37, 0.68]. Regression of FN onto SN pooling 35 and 46 DAT data revealed the following equation: $\log (\mathrm{SN})=0.51 * \mathrm{FN}+1.5\left(r^{2}\right.$ $=0.78, \mathrm{n}=71)$, with a $95 \%$ confidence interval of the slope $[0.45,0.58]$. The difference in data at 18 DAT might be explained in part by longevity of the sensor. When plants were harvested 18 DAT, the sensor had been used approximately 200 times in other experiments. The expected life span of a sensor is 200-400 readings, depending upon sampling procedures and storage conditions of the meter (equipment manual). While using the sensor at 18 DAT, the authors noticed the meter was difficult to calibrate and had to be corrected several times during the period of data collection. We believe the sensor was at the end of its expected life span, so subsequent readings were conducted with a new sensor. We believe this was the cause of the slight difference in response and lower $r^{2}$ value at 18 DAT.

Because confidence intervals for the estimated slopes and y-intercepts (data not shown) overlap for the two experiments, the data were pooled (except 18 DAT in Expt. 2) to determine a more precise equation: $\log (\mathrm{SN})$ $=0.47 * \mathrm{FN}+1.6\left[r^{2}=0.80, \mathrm{n}=132\right]$ (Fig. 3). Fonteno et al. (1996) reported FN sufficiency ranges for pansy as being $2.5 \%$ to $4.5 \%$. Using these values in the previous equation, $\mathrm{SN}$ levels for optimal pansy growth would be 600 to $5200 \mathrm{mg} \cdot \mathrm{L}^{-1} \mathrm{NO}_{3}^{-}-\mathrm{N}$. Our data and observations agree with the calculated lower limit for this range $\left(600 \mathrm{mg} \cdot \mathrm{L}^{-1} \mathrm{NO}_{3}^{-}\right)$. However, there were no plants that displayed symptoms of excessive $\mathrm{N}$ in our experiment, so we cannot be sure the upper limit $\left(5200 \mathrm{mg} \cdot \mathrm{L}^{-1} \mathrm{NO}_{3}^{-}\right)$is accurate. Nonetheless, growers and landscape professionals are typically concerned with $\mathrm{N}$ deficiency.

In summary, our data demonstrate the Cardy nitrate meter can be used to rapidly diagnose $\mathrm{N}$ deficiency in pansy. Because of the high degree of correlation with FN levels, $\mathrm{SN}$ values determined by the Cardy nitrate meter can be used to predict FN levels, and thus plant $\mathrm{N}$ status. In addition, similar to traditional foliar analysis, the Cardy nitrate meter values can predict deficient levels of $\mathrm{N}$ prior to the occurrence of visual symptoms in the plant. Also, samples used to determine the equation for the line of best fit were collected at five different sampling dates from $22 \mathrm{Dec}$. 2000 through 18 May 2001. Over this period of time, the relationship between $\mathrm{FN}$ and SN remained stable despite plants growing at different times of the year with different temperature and photoperiod exposures. These data indicate the Cardy nitrate meter values can be a reliable predictor of low $\mathrm{N}$ levels before the onset of visual symptoms, when used on plants grown throughout the winter and spring seasons.

\section{Literature Cited}

Beverly, R.B. 1994. Stem sap testing as a real-time guide to tomato seedling nitrogen and potassium fertilization. Commun. Soil Sci. Plant Anal. 25: 1045-1056.

Bullock, D.G. and D.S. Anderson. 1998. Evaluation of the Minolta SPAD-502 chlorophyll meter for nitrogen management in corn. J. Plant Nutr. 21: 741-755.

Cabrera, R.I. 1997. Comparative evaluation of nitrogen release patterns from controlled-release fertilizers by nitrogen leaching analysis. HortScience 32:669-673.

Coltman, R.R. 1988. Yields of greenhouse tomatoes managed to maintain specific petiole sap nitrate levels. HortScience 23:148-151.

Delgado, J.A. and R.F. Follett. 1998. Sap test to determine nitrate-nitrogen concentrations in aboveground biomass of winter cover crops. Commun. Soil Sci. Plant Anal. 29:545-559.

Diez, J., R. Roman, M. Cartagena, A. Vallejo, A. Bustos, and R. Caballero. 1994. Controlling nitrate pollution of aquifers by using different nitrogenous controlled release fertilizers in maize crop. Agr., Ecosystem and Environ. 48:49-56.

Fonteno, W.C., P.V. Nelson, and D.A. Bailey. 1996. Testing procedures for bedding plants. North Carolina Flower Growers' Bul. 41(2)1-11.

Guertal, E.A. 2000. Preplant slow-release nitrogen fertilizers produce similar bell pepper yields as split applications of soluble fertilizer. Agron. J. 92:388-393.

Hairston, J.E. and L. Stribling. 1995. Getting to know water: Understanding water as a resource. Alabama Coop. Ext. Circ. 790.

Hesselein, C.P., C.H. Gilliam, J.R. Kessler, and J.H. Edwards. 2000. Optimizing fertilization practices for 10-inch Boston fern production. Proc. South. Nurs. Assn. Res. Conf. 45:59-61.

Kirven, D.M. 1986. Horticultural testing: Is our language confusing? HortScience 21:215-217.

Kubota, A., T.L. Thompson, T.A. Doerge, and R.E. Godin. 1996. A petiole sap nitrate test for cauliflower. HortScience 31:934-937.

Marschner, H. 1997. Mineral Nutrition of Higher Plants, 2nd ed. Harcourt Brace \& Co., New York.

Miller, M.N. 2000. Double duty, double detail: Industry statistics. Grower Talks 63(15): 90-106.

Mills, H.A. and J.B. Jones, Jr. 1996. Plant analysis handbook. Micro-Macro Publishing, Athens, Ga.

Minotti, P.L. D.E. Halseth, and J.B. Sieczka. 1994. Field chlorophyll measurements to assess the nitrogen status of potato varieties. HortScience 29:1497-1500.

National Agriculture Statistics Service, Agricultural Statistics Board, and the U.S. Department of

Fig. 3. Relationship between foliar nitrogen (FN) and petiole sap nitrate concentration $(\mathrm{SN})\left(\mathrm{mgL}^{-1}\right)$ in pansy over Expts. 1 and 2. 
Agriculture. 2001. Floriculture Crops, 2000 Summary. http://www.usda.gov/nass/ (last accessed 12/03/01).

Neilsen, D., E.J. Hogue, L.C. Herbert, P. Parchomchuk, and G.H. Neilsen. 1995. Use of rapid techniques for estimating the $\mathrm{N}$ status of fertigated apple trees. Acta Hort. 383:211-218.

Neter, J., M.H. Kutner, C.J. Nachtsheim, and W. Waserman. 1996. Applied linear statistical models, $4^{\text {th }}$ ed. Times Mirror Higher Education Group, Chicago.

Rosen, C.J., M. Errebhi, and W. WenShan. 1996. Testing petiole sap for nitrate and potassium A comparison of several analytical procedures. HortScience 31:1173-1176.
Schenk, M.K. 1988. N-status of pot plants as evaluated by measurement of substrate and plant sap nitrate. Acta Hort. 221:253-260.

Sims, G.K., T.R. Ellsworth, and R.L. Mulvaney. 1995. Microscale determination of inorganic nitrogen in water and soil extracts. Commun. Soil Sci. Plant Anal. 26:303-316.

Smith, P.F. 1962. Mineral analysis of plant tissues. Annu. Rev. Plant Physiol. 13:81-108.

Syvertson, J.P. and M.L. Smith. 1995. Nitrogen leaching, $\mathrm{N}$ uptake efficiency and water use from citrus trees fertilized at three $\mathrm{N}$ rates. Proc. Fla. State Hort. Soc. 108:151-155.

Timmons, D.R. and A.S. Dylla. 1981. Nitrogen leaching as influenced by nitrogen management and supplemental irrigation level. J. Environ. Qual. 10:421-426.

Wood, C.W., P.W. Tracy, D.W. Reeves, and K.L. Edmisten. 1992. Determination of cotton nitrogen status with a hand-held chlorophyll meter. J. Plant Nutr. 15:1435-1448.

Yeager, T., C. Gilliam, T. Bilderback, D. Fare, A Niemiera, and K. Tilt. 1997. Best management practices: Guide for producing containergrown plants. Southern Nurserymen's Assn., Marietta, Ga.

Yeager, T.H., R.D. Wright, and S.J. Donahue. 1983. Comparison of pour-through and saturated pine bark extract N, P, K, and $\mathrm{pH}$ levels. J. Amer. Soc. Hort. Sci. 108:112-114. 